\title{
COMP and Col9A3 mutations and their relationship to the pseudoachondroplasia phenotype
}

\author{
WOON-WON JUNG ${ }^{1 *}$, GRACIA CIELO BALCE ${ }^{2 *}$, JAE-WOO CHO ${ }^{2}$, \\ SUNG-CHUL JUNG ${ }^{4}$, SUK-JOO HONG ${ }^{3}$ and HAE-RYONG SONG ${ }^{2}$ \\ ${ }^{1}$ College of Health Science, Korea University, Seoul 136-703; ${ }^{2}$ Department of Orthopaedics, Rare Diseases Institute; \\ ${ }^{3}$ Department of Radiology, Korea University Medical Center Guro Hospital, Seoul 152-703; \\ ${ }^{4}$ Department of Biochemistry, Ewha Women's University School of Medicine, Seoul 158-710, Republic of Korea
}

Received July 9, 2010; Accepted September 6, 2010

DOI: 10.3892/ijmm_00000538

\begin{abstract}
While pseudoachondroplasia (PSACH) is almost exclusively caused by cartilage oligomeric matrix protein (COMP) mutations, many patients identified with the PSACH phenotype do not have this mutation, suggesting gene and locus heterogeneity. In order to further characterize this entity, we studied 32 clinically and radiographically diagnosed PSACH patients, among 19 families. COMP and collagen (Col) IX (A1, A2 and A3) mutations, were determined. Patients who tested negative for pathological gene mutations but who were identified with the PSACH phenotype, were included. The phenotypes were characterized according to height deviation (cm) from normal, lower extremity mechanical axis deviation (MAD), cervical and thoracolumbar spine involvement, pelvic index, as well as hip, knee, ankle and hand involvement. We report an $81 \%$ mutation detection rate for $\mathrm{PSACH}$, of which $\mathrm{COMP}+\mathrm{Col} 9 \mathrm{~A} 3$ mutations were more prevalent $(61 \%)$ than COMP mutations alone $(30 \%)$. Of our PSACH patients, $19 \%$ tested negative for both COMP and Co19A3 mutations, and they presented with the greatest mean height deviations, but the least mean MADs. While all the PSACH mutations consistently produced the severe phenotype, the V426A mutation in Col9A3 produced the most severe. Mother-daughter and father-son phenotypic similarities were noted in the COMP+Co19A3 families. Co19A3 and gender play confounding roles in the phenotypic severity of PSACH. The presence of the PSACH phenotype in patients who tested negative for known mutations further confirms the genetic heterogeneity of this condition.
\end{abstract}

Correspondence to: Professor Hae-Ryong Song, Department of Orthopaedics, Rare Diseases Institute, Korea University Medical Center Guro Hospital, 80 Guro-Dong, Guro-Gu, Seoul 152-703, Republic of Korea

E-mail: songhae@korea.ac.kr

${ }^{*}$ Contributed equally

Key words: cartilage oligomeric matrix protein, Col9A3, pseudoachondroplasia

\section{Introduction}

Pseudoachondroplasia (PSACH) is a fairly common skeletal dysplasia clinically characterized by disproportionate shortlimbed dwarfism with normal intelligence and faces, joint laxity, premature osteoarthritis, and long bone deformities (1). Radiographically, PSACH patients can be classically characterized by the presence of atlantoaxial instability (AAI) (2), platyspondyly, and epimetaphyseal dysplasias of the long and short bones (3). PSACH is caused almost exclusively by autosomal dominant inherited mutations in the gene encoding cartilage oligomeric matrix protein (COMP), a homopentameric calcium-binding extracellular matrix protein (4-8), located on chromosome 19p12-13.1 (1). COMP mutations, however, are not exclusive to PSACH. Multiple epiphyseal dysplasia (MED), a relatively milder skeletal dysplasia involving the epiphyses of long bones (9), is also ascribed, albeit more heterogeneously, to this mutation (10). The PSACH phenotype involves a spectrum from severe to mild, and can occasionally overlap with the severe type of MED $(1,9)$, creating diagnostic dilemmas. Furthermore, the presence of the PSACH phenotype in patients with no mutation of the COMP gene also complicates the diagnosis. Hence, this study aimed to review and correlate the genotypic and phenotypic spectrum of PSACH in Korean patients, in order to further characterize this disease entity.

\section{Materials and methods}

Subjects. This study involved 32 PSACH patients, aged 4 to 73 years, belonging to 19 families (Table I) of Korean ethnicity. Among the $32 \mathrm{PSACH}$ patients, 15 were males and 17 were females. The PSACH diagnosis was primarily phenotypically agreed upon by a paediatric orthopaedic surgeon and a musculoskeletal radiologist. All the patients underwent gene mutation analysis, as described below. They were classified according to gene mutation and whether a specific amino acid was deleted or replaced in a specific codon. Patients with single nucleotide polymorphisms (SNPs), who tested negative for any known pathological mutations, but who were identified with the PSACH phenotype, were included. 
Table I. Patient age, gender, height deviations and specific mutations. ${ }^{a}$

\begin{tabular}{|c|c|c|c|c|c|c|}
\hline Family & $\begin{array}{l}\text { Family } \\
\text { member }\end{array}$ & $\begin{array}{l}\text { Age/ } \\
\text { gender }\end{array}$ & $\begin{array}{l}\text { Height } \\
(\mathrm{cm})\end{array}$ & $\begin{array}{c}\text { Deviation from } \\
\text { normal }(\mathrm{cm})\end{array}$ & Gene & Domain \\
\hline 1 & $\begin{array}{l}\text { Mother } \\
\text { Patient }\end{array}$ & $\begin{array}{l}43 / \mathrm{F} \\
16 / \mathrm{M}\end{array}$ & $\begin{array}{l}118 \\
103\end{array}$ & $\begin{array}{l}-43 \\
-29\end{array}$ & $\begin{array}{c}\mathrm{COMP}+\mathrm{Co} 19 \mathrm{~A} 3 \\
\mathrm{COMP}\end{array}$ & $\begin{array}{c}\mathrm{C} 328 \mathrm{R}+\mathrm{N} 324 \mathrm{I} \\
\mathrm{C} 328 \mathrm{R}\end{array}$ \\
\hline 2 & $\begin{array}{l}\text { Mother } \\
\text { Patient }\end{array}$ & $\begin{array}{l}33 / \mathrm{F} \\
10 / \mathrm{F}\end{array}$ & $\begin{array}{r}116 \\
89\end{array}$ & $\begin{array}{l}-43 \\
-48\end{array}$ & $\begin{array}{c}\mathrm{COMP}+\mathrm{Co} 19 \mathrm{~A} 3 \\
\mathrm{COMP}\end{array}$ & $\begin{array}{c}\mathrm{D} 473 \mathrm{G}+\mathrm{N} 324 \mathrm{I} \\
\mathrm{D} 482 \mathrm{~N}\end{array}$ \\
\hline 3 & $\begin{array}{l}\text { Father } \\
\text { Patient } \\
\text { Brother } \\
\text { Sister } \\
\text { Brother }\end{array}$ & $\begin{array}{l}43 / \mathrm{M} \\
17 / \mathrm{M} \\
14 / \mathrm{M} \\
12 / \mathrm{F} \\
10 / \mathrm{M}\end{array}$ & $\begin{array}{l}149 \\
143 \\
137 \\
135 \\
110\end{array}$ & $\begin{array}{l}-24 \\
-29 \\
-26 \\
-15 \\
-27\end{array}$ & $\begin{array}{c}\text { COMP+Co19A3 } \\
\text { COMP+Co19A3 } \\
\text { COMP } \\
\text { Col9A3 } \\
\text { COMP+Col9A3 }\end{array}$ & $\begin{array}{c}\text { Q456del+G17E } \\
\text { Q456del+G17E } \\
\text { Q456del } \\
\text { G17E } \\
\text { Q456del+G17E }\end{array}$ \\
\hline 4 & $\begin{array}{l}\text { Mother } \\
\text { Patient } \\
\text { Brother }\end{array}$ & $\begin{array}{l}43 / \mathrm{F} \\
12 / \mathrm{M} \\
8 / \mathrm{M}\end{array}$ & $\begin{array}{r}125 \\
83 \\
72\end{array}$ & $\begin{array}{l}-36 \\
-65 \\
-55\end{array}$ & $\begin{array}{l}\text { COMP+Col9A3 } \\
\text { COMP+Co19A3 } \\
\text { COMP+Co19A3 }\end{array}$ & $\begin{array}{c}\text { G456del+A435E } \\
\text { D472Y+N324I } \\
\text { D472Y+N324I }\end{array}$ \\
\hline 5 & $\begin{array}{l}\text { Mother } \\
\text { Sister } \\
\text { Patient } \\
\text { Daughter } \\
\text { Son }\end{array}$ & $\begin{array}{l}73 / \mathrm{F} \\
43 / \mathrm{F} \\
40 / \mathrm{M} \\
4 / \mathrm{F} \\
3 / \mathrm{M}\end{array}$ & $\begin{array}{r}141 \\
115 \\
140 \\
70 \\
72\end{array}$ & $\begin{array}{l}-20 \\
-46 \\
-33 \\
-31 \\
-23\end{array}$ & $\begin{array}{l}\text { COMP+Col9A3 } \\
\text { COMP+Co19A3 } \\
\text { COMP+Co19A3 } \\
\text { COMP+Co19A3 } \\
\text { COMP+Co19A3 }\end{array}$ & $\begin{array}{l}\text { G456del+A435E } \\
\text { G456del+A435E } \\
\text { G456del+V426A } \\
\text { G456del+A435E } \\
\text { G456del+V426A }\end{array}$ \\
\hline 6 & $\begin{array}{l}\text { Patient } \\
\text { Son }\end{array}$ & $\begin{array}{l}72 / \mathrm{F} \\
46 / \mathrm{M}\end{array}$ & $\begin{array}{l}101 \\
107\end{array}$ & $\begin{array}{l}-60 \\
-66\end{array}$ & $\begin{array}{c}\text { COMP+Co19A3 } \\
\text { Col9A } 1+C o 19 A 2\end{array}$ & $\begin{array}{l}\mathrm{D} 473 \mathrm{G}+\mathrm{N} 324 \mathrm{I} \\
\mathrm{S} 339 \mathrm{P}+\mathrm{Q} 326 \mathrm{R}\end{array}$ \\
\hline 7 & Patient & $10 / \mathrm{F}$ & 95 & -42 & COMP & D509N \\
\hline 8 & Patient & $5 / \mathrm{F}$ & 90 & -18 & COMP & D473del \\
\hline 9 & Patient & $25 / \mathrm{F}$ & 107 & -54 & COMP & D473del \\
\hline 10 & Patient & $35 / \mathrm{M}$ & 124 & -49 & COMP & G341del \\
\hline 11 & Patient & $41 / \mathrm{F}$ & 103 & -58 & COMP & D473del \\
\hline 12 & Patient & $23 / \mathrm{M}$ & 103 & -70 & COMP+Col9A3 & G456del+V426A \\
\hline 13 & Patient & $60 / \mathrm{M}$ & 165 & -8 & $\mathrm{COMP}+\mathrm{Co} 19 \mathrm{~A} 3$ & $\mathrm{R} 718 \mathrm{~W}+\mathrm{V} 426 \mathrm{~A}$ \\
\hline 14 & Patient & $12 / \mathrm{F}$ & 91 & -59 & Co19A $1+\operatorname{Col} 9 \mathrm{~A} 2$ & S339P+Q326R \\
\hline 15 & Patient & $21 / \mathrm{F}$ & 107 & -59 & Col9A $1+$ Col9A2 & S339P+Q326R \\
\hline 16 & Patient & $33 / \mathrm{F}$ & 125 & -36 & Co19A1+Col9A2 & S339P+Q326R \\
\hline 17 & Patient & $47 / \mathrm{M}$ & 125 & -48 & Col9A $1+$ Col9A 2 & S339P+Q326R \\
\hline 18 & Patient & $30 / \mathrm{F}$ & 96 & -65 & Co19A $1+C o 19 A 2$ & S339P+Q326R \\
\hline 19 & Patient & $52 / \mathrm{M}$ & 100 & -73 & Col9A3 & V426A \\
\hline
\end{tabular}

anherited mutations are shown in families 1 to 6 .

The phenotypes were characterized according to the following: i) Height deviation from the normal values in the Korean population (described in centimeters), ii) lower extremity mechanical axis deviation (MAD) (described in millimeters), iii) cervical spine involvement (AAI), iv) thoracolumbar spine involvement (anterior beaking, platyspondyly), v) pelvic index, and vi) the severity of epimetaphyseal involvement of the hip, knee, ankle and hand.

Chart and digital radiographical reviews and measurements were conducted by one paediatric orthopaedic surgeon and one musculoskeletal radiologist using the STAR PACS PiViewStar 5.0.8.1 Software by INFINITT. Lower extremity MAD was calculated using standing orthoroentgenograms by drawing a line from the center of the femoral head to the center of the ankle, and measuring the horizontal distance
Table II. Grading of the severity of epimetaphyseal involvement using plain radiographs.

\begin{tabular}{lll}
\hline Grade & \multicolumn{1}{c}{ Epiphysis } & \multicolumn{1}{c}{ Metaphysis } \\
\hline+ & Small \pm irregular borders & $\begin{array}{l}\text { No involvement } \\
\text { With defects, cupping, } \\
\text { or flaring }\end{array}$ \\
++ & Fragmented & $\begin{array}{l}\text { Deformed, widened, } \\
\text { or angulated }\end{array}$ \\
++ & Flattened & \\
\hline
\end{tabular}

from this line to the center of the knee. The AAI was calculated by measuring the distance from the odontoid to the posterior aspect of the anterior arch of the atlas in lateral 


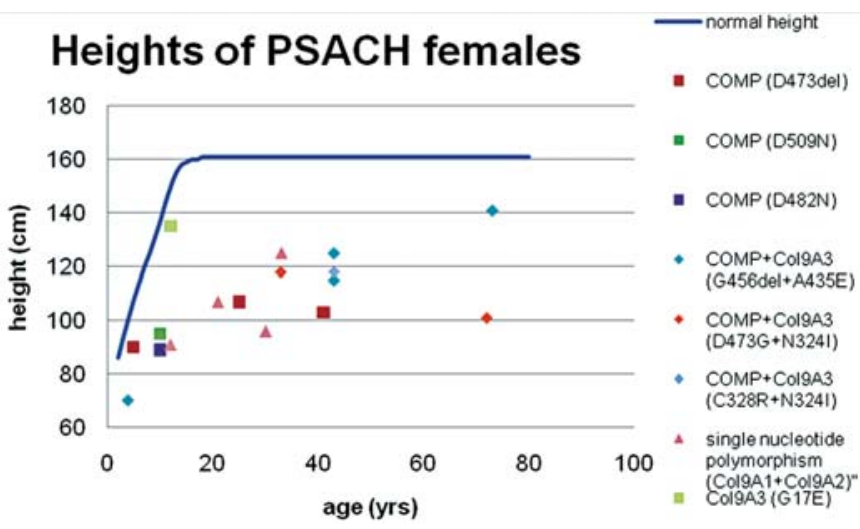

Figure 1. Graph showing the heights of PSACH females (according to mutation) against the normal height-for-age of Korean females.

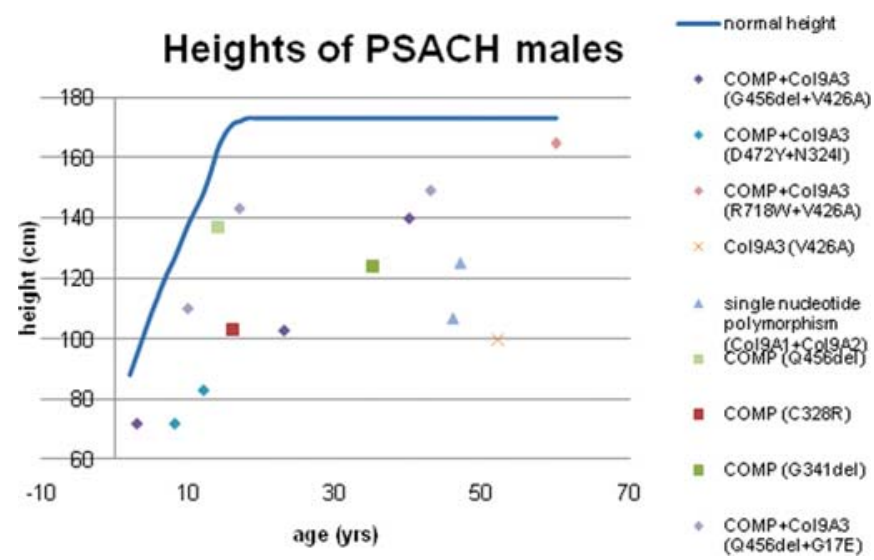

Figure 2. Graph showing the heights of PSACH males (according to mutation) against the normal height-for-age of Korean males.

Table III. Summary of the genotype-phenotype correlations in Korean PSACH patients.

\begin{tabular}{|c|c|c|c|c|c|c|c|c|c|c|}
\hline Mutation & $\begin{array}{c}\text { No. of } \\
\text { patients }\end{array}$ & $\begin{array}{l}\text { Mean height } \\
\text { deviation } \\
(\mathrm{cm})\end{array}$ & $\begin{array}{l}\text { Mean } \\
\text { MAD } \\
(\mathrm{mm})\end{array}$ & $\begin{array}{c}\text { Cervical } \\
\text { spine }\end{array}$ & $\begin{array}{l}\text { Thoraco- } \\
\text { lumbar } \\
\text { spine }\end{array}$ & $\begin{array}{l}\text { Pelvic } \\
\text { index }\end{array}$ & Hip & Knee & Ankle & Hand \\
\hline PSACH & 32 & -43 & 39 & AAI & $\mathrm{P}$ & $0.38 \pm 0.05$ & +++ & +++ & +++ & +++ \\
\hline COMP & 8 & -39 & 36 & AAI & $\mathrm{P}$ & $0.4 \pm 0.05$ & +++ & +++ & +++ & +++ \\
\hline D473del & 3 & -43 & 12 & AAI & $\mathrm{A} / \mathrm{P}$ & 0.39 & +++ & +++ & +++ & +++ \\
\hline D509N & 1 & -42 & 24 & 0 & $\mathrm{P}$ & 0.46 & +++ & +++ & +++ & ++ \\
\hline $\mathrm{D} 482 \mathrm{~N}$ & 1 & -48 & 42 & AAI & $\mathrm{A} / \mathrm{P}$ & 0.45 & +++ & +++ & +++ & +++ \\
\hline Q456del & 1 & -26 & 29 & AAI & $\mathrm{P}$ & 0.43 & +++ & +++ & +++ & +++ \\
\hline C328R & 1 & -29 & 50 & AAI & $\mathrm{P}$ & 0.3 & +++ & +++ & +++ & +++ \\
\hline G341del & 1 & -49 & 62 & 0 & $\mathrm{P}$ & 0.43 & +++ & +++ & +++ & +++ \\
\hline $\mathrm{COMP}+\mathrm{Co} 19 \mathrm{~A} 3$ & 16 & -37 & 39 & $\mathrm{AAI} / \mathrm{N}$ & $\mathrm{A} / \mathrm{P}$ & $0.42 \pm 0.06$ & +++ & +++ & +++ & +++ \\
\hline G456del+A435E & 4 & -33 & 19 & 0 & A & 0.39 & ++ & ++ & ++ & ++ \\
\hline $\mathrm{D} 473 \mathrm{G}+\mathrm{N} 324 \mathrm{I}$ & 2 & -51 & 19 & AAI & $\mathrm{P}$ & 0.47 & +++ & +++ & +++ & +++ \\
\hline $\mathrm{C} 328 \mathrm{R}+\mathrm{N} 324 \mathrm{I}$ & 1 & -43 & N/A & $\mathrm{N} / \mathrm{A}$ & N/A & 0.5 & +++ & +++ & +++ & +++ \\
\hline G456del+V426A & 3 & -42 & 87 & 0 & $\mathrm{~A}$ & 0.4 & +++ & +++ & +++ & +++ \\
\hline $\mathrm{D} 472 \mathrm{Y}+\mathrm{N} 324 \mathrm{I}$ & 2 & -60 & N/A & N/A & N/A & N/A & N/A & N/A & N/A & N/A \\
\hline $\mathrm{R} 718 \mathrm{~W}+\mathrm{V} 426 \mathrm{~A}$ & 1 & -8 & N/A & 0 & $\mathrm{P}$ & 0.38 & +++ & +++ & +++ & +++ \\
\hline Q456del+G17E & 3 & -26 & 33 & $\mathrm{AAI} / \mathrm{N}$ & $\mathrm{A} / \mathrm{P}$ & 0.43 & ++ & ++ & +++ & +++ \\
\hline Col9A3 & 2 & -44 & 59 & AAI & $\mathrm{P}$ & 0.3 & +++ & +++ & +++ & +++ \\
\hline V426A & 1 & -73 & 59 & AAI & $\mathrm{P}$ & 0.3 & +++ & +++ & +++ & +++ \\
\hline G17E & 1 & -15 & N/A & N/A & N/A & N/A & N/A & N/A & N/A & N/A \\
\hline $\begin{array}{l}\text { SNP in } \\
\text { Co19A1+Co19A2 } \\
(\mathrm{S} 339 \mathrm{P}+\mathrm{Q} 326 \mathrm{R})\end{array}$ & 6 & -54 & 25 & AAI & $\mathrm{P}$ & $0.42 \pm 0.03$ & +++ & +++ & +++ & +++ \\
\hline
\end{tabular}

A, anterior beaking; P, platyspondyly; N/A, data not available.

cervical spine flexion radiographs. Anterior beaking is positive when there is a protuberant beak-like structure on the anterior aspect of the vertebrae on lateral thoracolumbar spine radiographs. Platyspondyly is noted if there is flattening of the vertebra with reduced end-plate distance on lateral thoracolumbar spine radiographs. Pelvic index was obtained by dividing the inter-teardrop distance by the largest width of the pelvis (11). Grading for epimetaphyseal involvement is shown in Table II. Inter-observer variability was obtained.
Heights of individual PSACH patients were plotted against the normal height-for-age of Korean females (Fig. 1) and males (Fig. 2).

Gene mutation detection and analysis. After informed consent was given, blood samples were extracted from all the patients and relatives, and genomic DNA was obtained. This was done for all the patients included in this study. All exons containing the exon-intron junction regions of COMP, 
collagen (Col)9A1, Co19A2 and Co19A3, were amplified by polymerase chain reaction (PCR) (2700, Applied Biosystems). The PCR product was added to the sequencing reaction mixture. Cycle sequencing was performed in both directions to determine COMP, Col9A1, Co19A2 and Co19A3 specific base mutations. The cycle sequencing procedure was followed by the BigDye Terminator Cycle Sequencing Kit (Applied Biosystems, Foster City, CA), and the reaction mixture was analyzed on an ABI Prism 3100 DNA Sequencer (Applied Biosystems). The sequencing data were analyzed with Seqscape Software version 2.5 (Applied Biosystems). Reference nucleotide sequences were obtained from NCBI GenBank. The mutations obtained were checked against those from 41 normal patients to rule out non-pathological mutations.

\section{Results}

The adult height range of Korean female PSACH patients is 96-141 cm (mean, $114 \mathrm{~cm}$ ). The heights of female PSACH patients against normal values for age are shown in Fig. 1. The adult height range of Korean male PSACH patients is $100-165 \mathrm{~cm}$ (mean, $123 \mathrm{~cm}$ ). The adult heights of male PSACH patients against normal values for age are shown in Fig. 2. The mean height deviation for both male and female PSACH patients was $-40 \mathrm{~cm}$ from the normal height for age. The mean height deviation for all PSACH patients in this study was $-43 \mathrm{~cm}$.

We report an $81 \%$ mutation detection rate for PSACH. Of these, $30 \%$ were positive for pure COMP mutations. There were 6 types of pure COMP mutations identified: D473del, D509N, D482N, C328R, G341del and Q456del. A 35-yearold male patient with G341del exhibited the greatest height deviation from the normal $(-49 \mathrm{~cm})$. He also had the greatest MAD of $62 \mathrm{~mm}$ in varus. AAI was noted in those patients with D473del, D482N, C328R and Q456del mutations. Platyspondyly and anterior beaking were found in most patients with the COMP mutations. The patient with C328R had the narrowest triangular pelvis (pelvic index, 0.3), and the one with D509N had a square-shaped pelvis (pelvic index, 0.46). All patients with COMP mutations had severe epimetaphyseal involvement of the hips, knees, ankles and hands (Table III).

COMP+Col9A 3 comprised $61 \%$ of those patients positive for PSACH mutations. There were 7 types of COMP+Col9A3 mutation combinations: G456del+A435E, D473G+N324I, C328R+N324I, G456del+V426A, D472Y+N324I, R718W+ V426A and Q456del+G17E. The 2 male siblings (Table I) with $\mathrm{D} 472 \mathrm{Y}+\mathrm{N} 324 \mathrm{I}$ had the greatest height deviations from normal, with the 8 -year-old at $72 \mathrm{~cm}(-55 \mathrm{~cm}$ from normal) and his 12-year-old brother at $83 \mathrm{~cm}(-65 \mathrm{~cm}$ from normal). The 3 patients with G456del+V426A had the greatest mean MAD of $87 \mathrm{~mm}$ in varus. AAI was seen in patients with D473G+N324I. Platyspondyly was generally seen in patients with COMP+Col9A3. The 60-year-old male with R718W+ $\mathrm{V} 426 \mathrm{~A}$ had the narrowest triangular pelvis (pelvic index, 0.38), and the 43-year-old female with C328R+N324I had a square-shaped pelvis (pelvic index, 0.5). The mother in family 1 (Table I) with the COMP+Col9A3 mutation had a greater height deviation compared to her son, who had the
$\mathbf{A}$

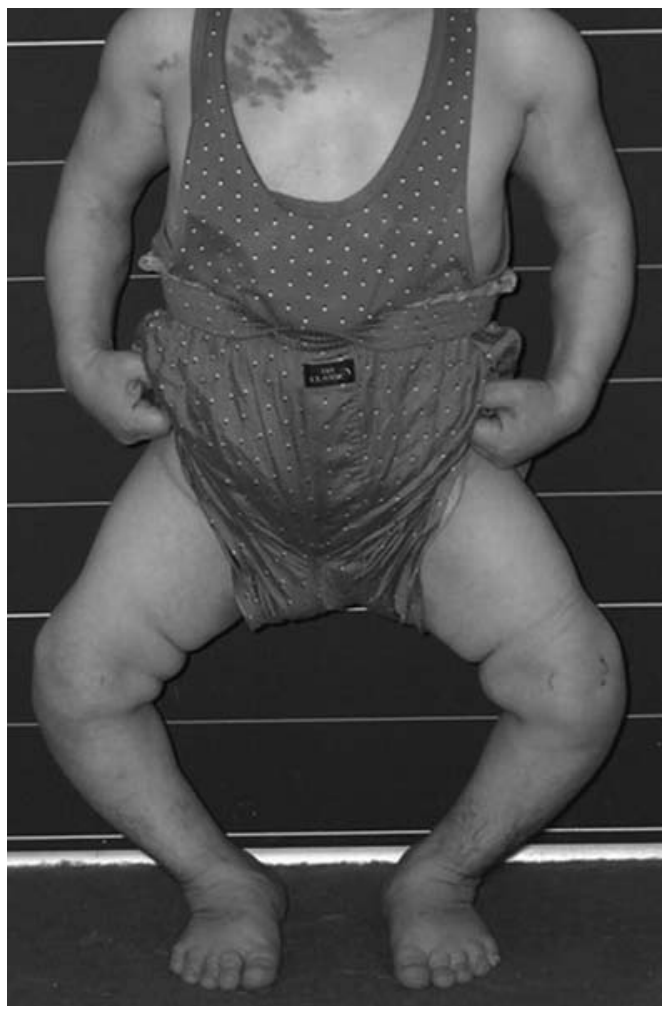

B

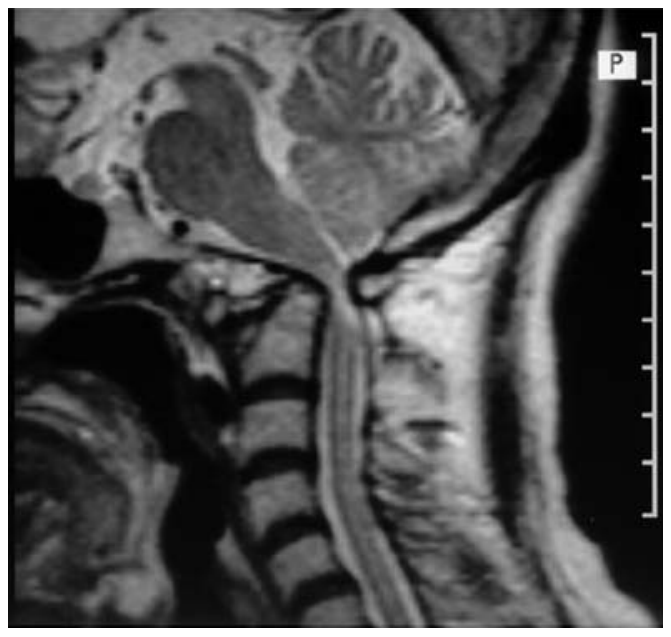

C

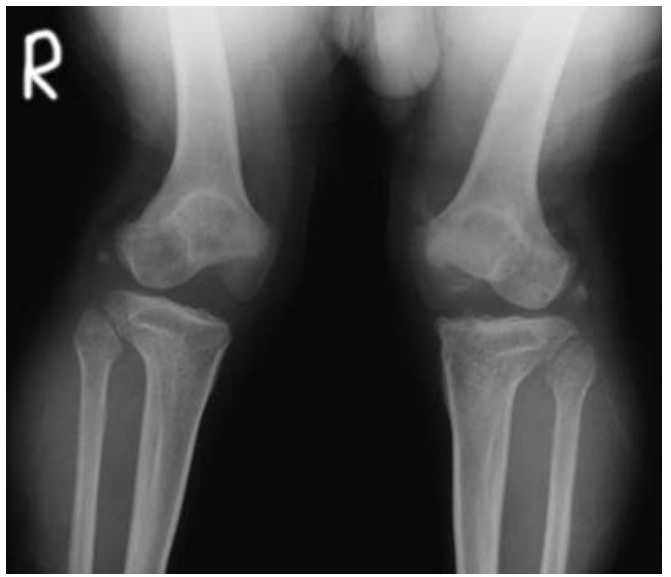

Figure 3. Fifty-two-year-old male with a V426A mutation in Co19A3, presenting with the most severe PSACH phenotype among our patients. (A) Standing clinical photo, showing short stature $(100 \mathrm{~cm})$, short limbs, and severe genu varum. (B) Sagittal MRI of his cervical spine showing spinal cord compression due to AAI. (C) Valgus stress radiograph of both knees, showing ligament laxity. 
A

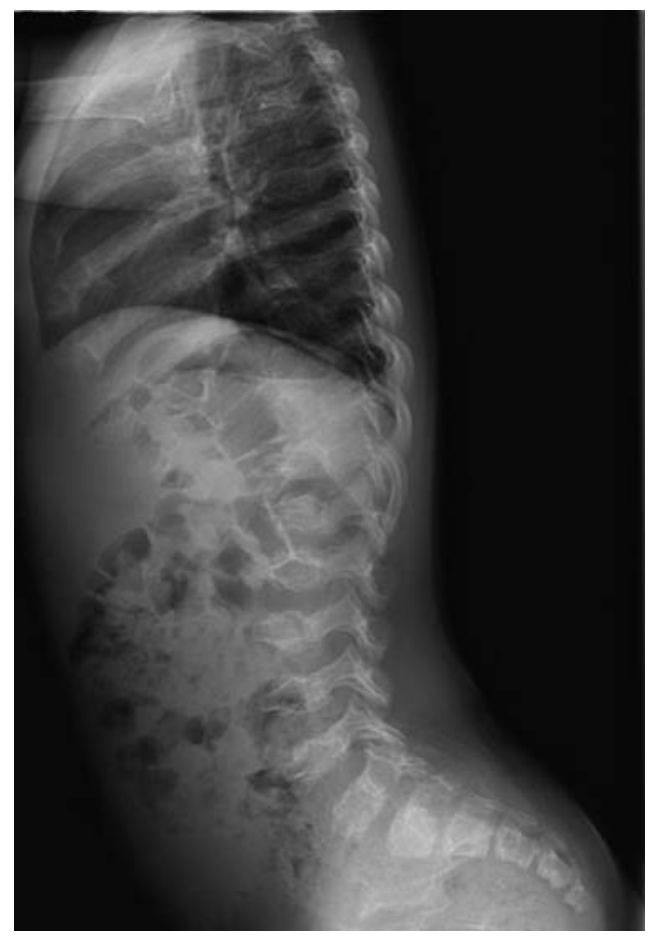

C

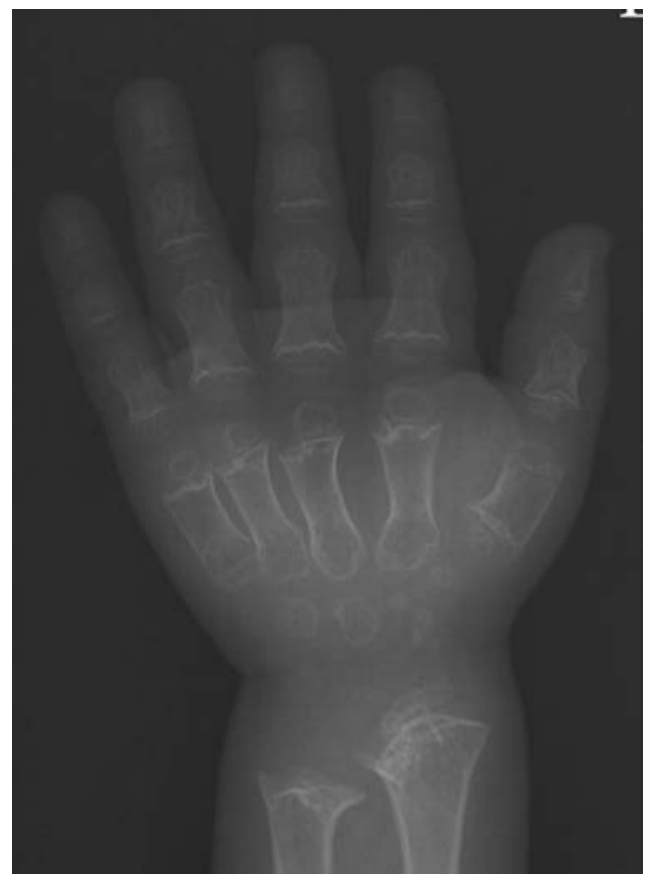

B

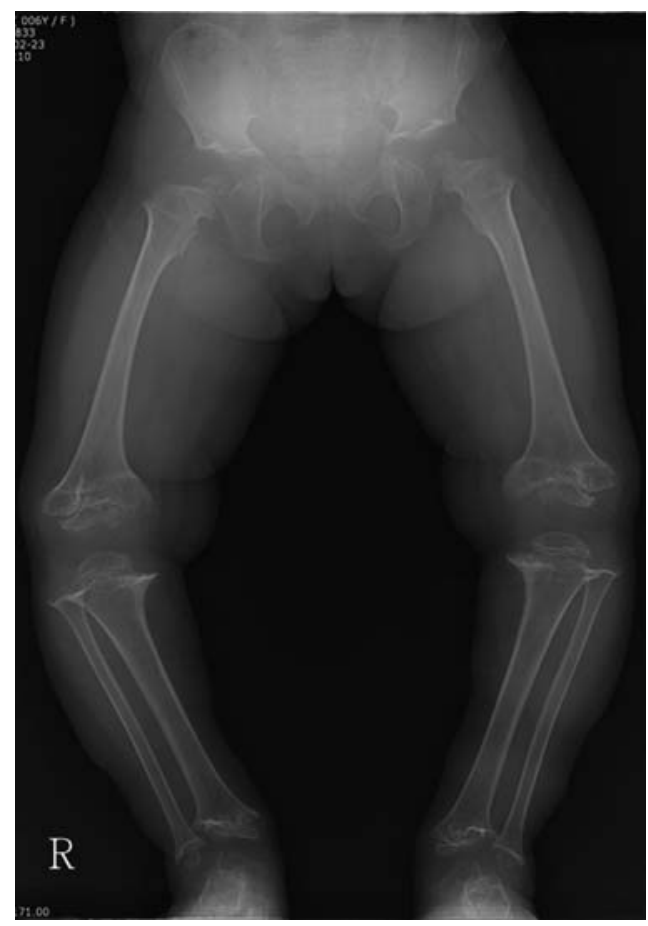

$\mathbf{D}$

Figure 4. Typical radiographical findings in a child. Shown is a 10-year-old PSACH female with a D482N mutation of the COMP gene. Her height was $89 \mathrm{~cm}$. (A) Lateral thoracolumbar spine radiograph showing anterior beaking of the vertebrae. (B) Standing orthoroentgenogram showing severe genu varum and severe epimetaphyseal involvement of the hips, knees and ankles. (C) Hand anteroposterior radiograph showing severe involvement of the carpals and epimetaphyses of the metacarpals and phalanges. (D) Anteroposterior radiograph of the pelvis showing narrowing of inter-teardrop distances, widened triradiate cartilages, irregular and sclerotic acetabulums, small and fragmented capital femoral epiphyses, and flared, shortened, distorted femoral necks.

COMP only mutation. However, the mother in family 2 (Table I) with the COMP+Col9A 3 mutation, had a presentation similar to her daughter, who had the COMP only mutation. The father in family 3 (Table I) with the COMP+Co19A3 mutation had the same phenotype as his sons with the COMP+Co19A3 and COMP mutations, but his daughter, who had only the Col9A3 mutation, had the less severe phenotype. In families where the COMP+Co19A3 mutation was fully penetrant, the offspring had the more severe phenotypes, as seen in families 4 and 5 (Table I). Generally, patients with the COMP+Col9A3 mutation had severe epimetaphyseal involvement of the hips, knees, ankles and hands (Table III).

There were only 2 patients with a Col9A 3 mutation. One was male and one was female. The 12-year-old female had a father and brothers with $\mathrm{COMP}+\mathrm{Co} 19 \mathrm{~A} 3$ mutations, as 
mentioned in Table I. She had a G17E mutation in Co19A3, and had less severe short stature $(-15 \mathrm{~cm}$ height deviation from normal). The male patient with a V426A mutation in Col9A3 (Fig. 3A), however, had the severe phenotype in all aspects: A height deviation of $-73 \mathrm{~cm}$ from normal, a MAD of $102 \mathrm{~mm}$ in varus on the left knee, AAI (Fig. 3B), platyspondyly, scoliosis, a narrow triangular pelvis (pelvic index, 0.3 ), ligament laxity (Fig. 3C), and severe epimetaphyseal involvement of the hips, knees, ankles and hands (Table III).

There were 6 patients who had the PSACH phenotype, and had SNPs in Co19A1+Co19A2 (S339P+Q326R). Their mean height deviation was $-54 \mathrm{~cm}$ from normal. Mean MAD was $25 \mathrm{~mm}$ in varus. They exhibited AAI, platyspondyly, and severe epimetaphyseal involvement of the hips, knees, ankles and hands (Table II).

Among our PSACH patients, the ones with SNPs presented with the shortest stature (mean height deviation $-59 \mathrm{~cm}$ from normal). Among those with mutations, however, the V426A mutation in Col9A3 resulted in the shortest stature and the most severe phenotype (Fig. 3A-C). However, there was only one patient with this mutation, and it may not be prudent to conclude from his presentations, as it could be an isolated event.

Inter-observer variability was $14 \%$ for detecting cervical spine abnormalities, and $17 \%$ for thoracolumbar spine abnormalities. Inter-observer variability was $7 \%$ for grading hip severity, $14 \%$ for knee severity, $17 \%$ for ankle severity, and $21 \%$ for hand severity.

\section{Discussion}

Wynne-Davies et al (12) classically described PSACH as having a variety of phenotypes. However, not much radiological delineation could be done, as all of the patients presented with severe involvement of all the joints. They also referred to height as the most reliable criterion for indicating severity in PSACH. Radiographically, PSACH patients typically have platyspondyly (Fig. 4A), genu varum and severe epimetaphyseal involvement of the hips, knees, ankles and hands (Fig. 4B-D). Through the different amino acid and codon specific mutations, we demonstrate here that there is a consistent severe epimetaphyseal involvement of the hips, knees, ankles and hands. Cervical and thoracic spine involvement is also consistently seen. In addition to height, though, the MAD should also be considered as a reliable radiological parameter in describing the severity of PSACH. It is indicative of osteoarthritis, as well as the presence of ligament laxity and joint instability.

There are around 60 known mutations in the COMP gene that cause PSACH. In our patient population, however, there were only 10 different COMP mutations.

In-frame deletions of 1 of 5 consecutive GAC codons for aspartic acid residues at positions 469-473 of COMP, are found in $30 \%$ of affected persons (13-15). In our 8 patients with COMP mutations, $3(37 \%)$ had the D473del mutation. Briggs et al (16) formerly described a family with severe PSACH with a substitution of arginine for cysteine at residue 328 (C328R). Their findings correspond to the severe PSACH phenotype exhibited by 2 affected patients in this study. Similarly, severe PSACH with the D473G mutation described by Ikegawa et al (3), was also found in 2 of our affected patients.

Most studies to date still portray that PSACH is almost exclusively caused by COMP gene mutations. However, we found that some of our clinically diagnosed PSACH patients actually had combined COMP+Co19A3 mutations, isolated Co19A3 mutations, or SNPs in Co19A1+Co19A2. To our knowledge, there are no accounts of Col9A3 mutations in PSACH in any study. MED patients with Col9A3 mutations present with mild phenotypic changes. They have normal heights, no brachydactyly, and their joint changes are indistinguishable from those of common idiopathic osteoarthritis $(17,18)$. It is evident from our results that, unlike in MED, Co19A3 mutations can play a strong role in promoting phenotypic severity in PSACH, particularly when a V426A mutation occurs. Our results are also consistent with those of Bonnemann et al (17) and Nakashima et al (18), namely that males with Co19A3 mutations have more severe manifestations than female patients. However, their data are on MED. Our lone male patient with a pure Col9A3 mutation had the most severe phenotype among all the PSACH subjects studied, even more severe than the most severe COMP mutation. The manifestation of short stature and/or severe radiographical findings in patients with isolated Co19A3 mutations, specifically V426A and G17E, which are also found in COMP+Co19A3 combined mutations, proves that these Col9A3 mutations are disease-causing, and not merely modifiers. Admittedly, though, conclusions regarding the relationship of phenotypic severity with the presence of Co19A3 mutations are weak, limited, and are essentially withheld at this point, as we only had 2 patients with isolated Col9A3 mutations.

The mother-to-daughter and father-to-son familial phenotypic severity patterns point to gender as a potential confounder in genotypic-phenotypic diversity in these individuals, and should be investigated further.

In a previous study by Czarny-Ratajczak et al (19), the S339P mutation in Col9A1 and the Q326R mutation in Co19A2, were noted as neutral polymorphisms or SNPs for MED. However, 19\% of our phenotypic PSACH patients who had combined SNPs in Col9A1 and Col9A2 displayed greater mean height deviations $(-54 \mathrm{~cm}$ from normal) than those with known and accepted mutations for PSACH. Their mean MADs were, however, the least significant, at $25 \mathrm{~mm}$ in varus. They also consistently presented with platyspondyly and severe epimetaphyseal involvement of hips, knees, ankles and hands. The presence of the PSACH phenotype in patients with SNPs in Co19A1+Col9A2 suggests that there could be other genes involved in this disease entity and further confirms that it is not as genetically homogeneous as previously reported.

In summary, our results show that while the majority of patients with PSACH have the COMP mutation, it more frequently occurs combined with a Col9A3 mutation. The involvement of the Co19A3 mutation in perpetuating the prevalence and severity of this disease entity, especially when it occurs alone, particularly in a male, needs further investigation. Gender plays a confounding role in phenotypic severity. There is also a need to investigate other genes that could be responsible for this disease entity. 


\section{Acknowledgements}

This study was supported by grants from the Korea Healthcare Technology Research and Development Project (no. A080588 and A090084), Ministry of Health, Welfare and Family Affairs, Republic of Korea.

\section{References}

1. Song HR, Lee KS, Li QW, Koo SK and Jung SC: Identification of cartilage oligomeric matrix protein (COMP) gene mutations in patients with pseudoachondroplasia and multiple epiphyseal dysplasia. J Hum Genet 48: 222-225, 2003.

2. Shetty GM, Song HR, Unnikrishnan R, Suh SW, Lee SH and Hur CY: Upper cervical spine instability in pseudoachondroplasia. J Pediatr Orthop 27: 782-787, 2007.

3. Ikegawa S, Ohashi H, Nishimura G, Kim KC, Sannohe A, Kimizuka M, Fukushima Y, Nagai T and Nakamura Y: Novel and recurrent COMP (cartilage oligomeric matrix protein) mutations in pseudoachondroplasia and multiple epiphyseal dysplasia. Hum Genet 103: 633-638, 1998.

4. Briggs MD: Recent advances in elucidating the molecularpathogenetic mechanisms of osteochondrodysplasias. Curr Opin Orthop 13: 333-338, 2002.

5. Tandon A, Bhargava SK, Goel S and Bhatt S: Pseudoachondroplasia: A rare cause of rhizomelic dwarfism. Indian J Orthop 42: 477-479, 2008.

6. Tufan AC, Satiroglu-Tufan NL, Jackson GC, Semerci CN, Solak S and Yagci B: Serum or plasma cartilage oligomeric matrix protein concentration as a diagnostic marker in pseudoachondroplasia: Differential diagnosis of a family. Eur J Hum Genet 15: 1023-1028, 2007.

7. Unger S: A genetic approach to the diagnosis of skeletal dysplasia. Clin Orthop Relat Res 401: 32-38, 2002.

8. Unger S and Hecht JT: Pseudoachondroplasia and multiple epiphyseal dysplasia: New etiologic developments. Am J Med Genet 106: 244-250, 2001.

9. Vatanavicharn N, Lachman RS and Rimoin DL: Multilayered patella: Similar radiographic findings in pseudoachondroplasia and recessive multiple epiphyseal dysplasia. Am J Med Genet A 146A: 1682-1686, 2008.

10. Mabuchi A, Manabe N, Haga N, Kitoh H, Ikeda T, Kawaji H, Tamai K, Hamada J, Nakamura S, Brunetti-Pieri N, Kimizuka M, Takatori Y, Nakamura K, Nishimura G, Ohashi H and Ikegawa S: Novel types of COMP mutations and genotype-phenotype association in pseudoachondroplasia and multiple epiphyseal dysplasia. Hum Genet 112: 84-90, 2003.
11. Matsui Y, Yasui N, Kimura T, Tsumaki N, Kawabata H and Ochi T: Genotype phenotype correlation in achondroplasia and hypochondroplasia. J Bone Joint Surg Br 80: 1052-1056, 1998.

12. Wynne-Davies R, Hall CM and Young ID: Pseudoachondroplasia: Clinical diagnosis at different ages and comparison of autosomal dominant and recessive types. A review of 32 patients (26 kindreds). J Med Genet 23: 425-434, 1986.

13. Briggs MD, Mortier GR, Cole WG, King LM, Golik SS, Bonaventure J, Nuytinck L, De Paepe A, Leroy JG, Biesecker L, Lipson M, Wilcox WR, Lachman RS, Rimoin DL, Knowlton RG and Cohn DH: Diverse mutations in the gene for cartilage oligomeric matrix protein in the pseudoachondroplasia-multiple epiphyseal dysplasia disease spectrum. Am J Hum Genet 62: 311-319, 1998.

14. Delot E, King LM, Briggs MD, Wilcox WR and Cohn DH: Trinucleotide expansion mutations in the cartilage oligomeric matrix protein (COMP) gene. Hum Mol Genet 8: 123-128, 1999.

15. Kennedy J, Jackson G, Ramsden S, Taylor J, Newman W, Wright MJ, Donnai D, Elles R and Briggs MD: COMP mutation screening as an aid for the clinical diagnosis and counseling for patients with a suspected diagnosis of pseudoachondroplasia or multiple epiphyseal dysplasia. Eur J Hum Genet 13: 547-555, 2005.

16. Briggs MD, Hoffman SMG, King LM, Olsen AS, Mohrenweiser H, Leroy JG, Mortier GR, Rimoin DL, Lachman RS, Gaines ES, Cekleniak JA, Knowlton RG and Cohn DH: Pseudoachondroplasia and multiple epiphyseal dysplasia due to mutations in the cartilage oligomeric matrix protein gene. Nat Genet 10: 330-336, 1995.

17. Bonnemann CG, Cox GF, Shapiro F, Wu JJ, Feener CA, Thompson TG, Anthony DC, Eyre DR, Darras BT and Kunkel LM: A mutation in the alpha 3 chain of type IX collagen causes autosomal dominant multiple epiphyseal dysplasia with mild myopathy. Proc Natl Acad Sci USA 97: 1212-1217, 2000.

18. Nakashima E, Kitoh H, Maeda K, Haga N, Kosaki R, Mabuchi A, Nishimura G, Ohashi H and Ikegawa S: Novel Col9A3 mutation in a family with multiple epiphyseal dysplasia. Am J Med Genet A 132A: 181-184, 2005.

19. Czarny-Ratajczak M, Lohiniva J, Rogala P, Kozlowski K, Perala M, Carter L, Spector TD, Kolodziej L, Seppanen U, Glazar R, Krolewski J, Latos-Bielenska A and Ala-Kokko L: A mutation in Col9A1 causes multiple epiphyseal dysplasia: Further evidence for locus heterogeneity. Am J Hum Genet 69: 969-980, 2001. 